\title{
OPEN
}

\section{Author Correction: Metabolomics reveals perturbations in endometrium and serum of minimal and mild endometriosis}

\author{
Mainak Dutta, Brajesh Singh, Mamata Joshi, Debanjan Das, Elavarasan Subramani, \\ Meenu Maan, Saikat Kumar Jana, Uma Sharma, Soumen Das, Swagata Dasgupta $\mathbb{D}_{\text {, }}$ \\ Chaitali Datta Ray, Baidyanath Chakravarty \& Koel Chaudhury
}

Correction to: Scientific Reports https://doi.org/10.1038/s41598-018-23954-7, published online 24 April 2018

In the original version of this Article, Mainak Dutta was incorrectly affiliated with 'Department of Biotechnology, Birla Institute of Technology Pilani (Dubai Campus), Dubai, United Arab Emirates'. The correct affiliation is listed below.

Department of Biotechnology, Birla Institute of Technology and Science, Pilani (Dubai Campus), Dubai, United Arab Emirates.

This error has now been corrected in the PDF and HTML versions of the Article, as well as in the Supplementary Information file.

(c) (i) Open Access This article is licensed under a Creative Commons Attribution 4.0 International License, which permits use, sharing, adaptation, distribution and reproduction in any medium or format, as long as you give appropriate credit to the original author(s) and the source, provide a link to the Creative Commons license, and indicate if changes were made. The images or other third party material in this article are included in the article's Creative Commons license, unless indicated otherwise in a credit line to the material. If material is not included in the article's Creative Commons license and your intended use is not permitted by statutory regulation or exceeds the permitted use, you will need to obtain permission directly from the copyright holder. To view a copy of this license, visit http://creativecommons.org/licenses/by/4.0/.

(c) The Author(s) 2020 